\title{
Apriorist Self-Interest: How it Embraces Altruism and is Not Vacuous
}

\author{
J. C. Lester
}

\section{Introduction}

This essay is part of an attempt to reconcile two extreme views in economics: the (neglected) subjective, apriorist approach and the (standard) objective, scientific (i.e., falsifiable) approach. The Austrian subjective view of value, building on Carl Menger's theory of value, was developed into a theory of economics as being entirely an a priori ${ }^{1}$ theory of action. ${ }^{2}$ This probably finds its most extreme statement in Ludwig von Mises' Human Action (1949). In contrast, the standard economic view has developed into making falsifiable predictions about economic phenomena whereby the truth of the assumptions, especially about economic agents, is relatively unimportant: predictive fecundity is all. This finds an extreme statement in Milton Friedman's introductory essay in his Essays in Positive Economics (1953). However, many economists fall somewhere between the two extremes, such as McKenzie and Tullock (1978). ${ }^{3}$

As a consequence, Austrian economics has fallen out of favor with most economists for not being scientific (falsifiable), while standard economics has fallen out of favor with many non-economists for being insufficiently linked with the real subjective aspects of human values, especially welfare, liberty, and morality. I generally view Austrians as correct on an a priori core. It is also quite valid to argue by drawing out the logical consequences of, say, rent control or minimum wage laws ceteris paribus. It is absurd to dismiss such arguments completely in favor of empirical tests. But I shall not here be attempting the immense project of adjudicating between (or, perhaps, marrying the best parts of each of) the two approaches to economics in areas other than the self-interest aspect of the rationality assumption. ${ }^{1}$

We need to look at the problem in more detail. Economics-particularly the Austrian, Chicago, and Virginia schools-is the social science that has ostensibly most linked the free market with liberty and welfare. Instrumental rationality, a basic assumption of economics, can appear to be unrealistic or viciously vacuous (depending on how one interprets it), and this therefore has a tendency to undermine its conclusions. The standard interpretation of instru-

J. C. Lester, Philosophy, Middlesex University, White Hart Lane, London N17 8HR England. 
mental rationality (as found in, say, Hirshleifer, 1984) has people as self-interestedly maximizing, over time, their utility as revealed by their preferences. This essay is not about defending this standard outlook directly. In particular, I readily concede here that people are not always "self-interested" in the sense of being egoistic, for I deny that economics needs to assume this. I also admit that people can make mistakes concerning their long-term interests (but the empirical literature can in part show that people are better off making and learning from their own mistakes than having others control them, and some philosophical arguments can contribute to showing that this is so as well). Instead, I defend an a priori interpretation of the standard instrumental-rationality formulation.

I take the following to outline the major objections to the idea that agents are self-interested utility-maximizers:

1. The Self and its Interests: This requires a complex philosophical and empirical account of the self (which is malleable rather than fixed and which has multiple identities) and its interests (about which the self can be mistaken, or socially determined, or weak-willed).

2. Self-Interest: People are not merely self-interested, for they often consider the interests of others, notably in moral decisions. Complete self-sacrifice is possible.

3. Utility: However one glosses "utility" (pleasure, happiness, etc.), it does not make sense as the single motive or goal. There are many things we want, and we cannot reduce them to a homogeneous desire or aim.

4. Utility-Maximization: People do not maximize anything in particular, let alone "utility." Their diverse activities are incommensurable in terms of value.

This essay deals only with the second of these, but it should help to give immediately a similar outline of each of these terms as I would defend them against the objections listed above:

1. The Self and Its Interests: Any single thing is a self in a general and innocuous sense: "the thing itself." The term does not have to imply anything about the nature of persons or of personal identity. It is irrelevant that there are important philosophical and empirical problems about the "self" in that sense. Further, anything that has desires has interests in the sense intended: things it is interested in achieving. ${ }^{5}$ It is not necessary that these desires be held self-consciously (or reflectively) and continuously; it is sufficient that some kind of desire motivates behavior.

2. Self(-Perceived)-Interest: The self-interest assumption is not to be contrasted with altruism - with which it is compatible-but with being an unconscious automaton or without a spontaneous will of one's own. Agents, qua agents, follow their consciously felt, self-perceived interests or desires.

3. Utility: What one desires or wants to do, one has utility (psychological satisfaction) at the thought of doing. Striving for want-satisfaction, or to avoid want-dissatisfaction in the case of disutility, must be what motivates agents.

4. Utility-Maximization: What one has the strongest desire to do, one has the strongest utility at the thought of doing. Agents aim at the goal the thought of which gives them the greatest utility, or least disutility, at the time of aiming at it (again, no great selfconsciousness is being presupposed, e.g., the "thoughtless" scratching of an itch is more want-satisfying than any alternative that occurs to us at the time). 
Thus I am roughly defending the a priori, or subjective, approach to rationality (not to economics as a whole) as expounded in Mises (1949) and Kirzner (1960). According to this view, introspection and reason show that agents are instrumentally rational in the sense of purposeful maximizers. I prefer to label instrumental rationality explicitly as "self-interested utility-maximization" in a clearer attempt to tie the a priori view to the standard view.

It might seem to many economists that I am defending a straw man. The literal truth of the rationality assumption is often thought to be unimportant for the general business of doing economics. Gary Becker (1962) has even argued that with no rationality assumption there would, with a high probability, still be downward sloping demand curves due to limited income (and so economic analysis and falsifiable predictions). So one might question whether the economic work I am wanting to defend need or can be interpreted using an a priori conception of instrumental rationality. However, from a purely economic viewpoint, it seems that we need a defense of instrumental rationality as a descriptive account of what agents are trying to do efficiently (they are a priori instrumentally rational in the sense of trying to make the best of things; but they need not be instrumentally rational in the sense of succeeding in this aim); for if agents are not trying to be efficiently instrumentally rational, then it is hard to make any real sense of their behavior. Consequently, the prescriptive accounts (as given by economists in their advisory role) of efficient instrumental rationality (of what people really need to do to achieve certain ends) must carry very little weight. So will all the results based on the additional rule-of-thumb assumptions (such as firms being profit-maximizers ${ }^{6}$ and individuals efficiently maximizing want-satisfaction over time) that also implicitly approximate to, or build on, the subjective instrumental rationality of agents. Standard economics cannot entirely abandon the core, a priori, subjective aspect of their science without producing mere predictions about prices and patterns of behavior that are impossible to relate to real human purposes. ${ }^{7}$

One of the most controversial aspects of the rationality assumption of economics is its interpretation of what it means to be "self-interested." It is often held to be either substantive and false, or tautological and vacuous. Here I defend the view that it is a priori but illuminating.

\section{Self-Interest and Altruism}

First I will examine the ways that self-interest and altruism are thought incompatible, and I will explain the apriorist view. Then we look at the problem posed for this view by the way that the nature of morals are often (mis)understood. This account is then briefly tested against a few typical incompatible views. It is important to bear in mind here that the compatibility of Austrian economics' apriorist sense of self-interest and altruism is intended to be a purely conceptual point about agents' choices. The critics discussed often fall into error by interpreting the issue as about contingent human nature.

\section{The Logic of Altruism}

Many early economists, and proto-economists, and most modern economists have assumed that people are egoistic; thus these economists have ruled out altruism. ${ }^{8}$ If they use the term "self-interest," they mean only egoism. They are here taken to be, at least implicitly, against the apriorist idea that economics can use an assumption of self-interest that means 
merely interests of the self, or self-perceived interests, and which coherently embraces both egoism and altruism without thereby being vacuous.

For instance, in The Leviathan, Hobbes assumes that "of all Voluntary Acts, the Object is to every man his own Good" (1651/1943, p. 78). All apparent acts of altruism are to be explained as disguised self-seeking. Hobbes found the idea of a person's benefiting another for the others' sake to be at best an implausible, and possibly an inconsistent, view of human motivation. In John Aubrey's Brief Lives, we are told that when asked why Hobbes had given alms to a beggar, Hobbes replied that it was to relieve his own distress at seeing the beggar's distress.

Edgeworth states that "the first principle of Economics is that every agent is actuated only by self-interest" (1881, p. 16). Though he later admits that in reality "man is for the most part an impure egoist, a mixed utilitarian" (p. 104). So the assumption is merely a generally useful one for Edgeworth. Gary Becker (e.g., his 1976) is noted for rigorously and consistently applying basic economic assumptions to areas normally considered outside the field of economics. ${ }^{9} \mathrm{He}$ admits the existence of altruism, but even he assumes that this must be a separate motive, with others, from self-interest as used by economics, which is "tassumed to dominate all other motives, with a permanent place also assigned to benevolence to children" (Becker, 1971). So Becker follows Edgeworth's one hundred years older opinion in finding the selfinterest assumption extremely fruitful though not completely true. ${ }^{10}$

We even find a moral philosopher, David Gauthier, telling us that "this conception, of persons as taking no interest in one another's interests, is fundamental not only to economics, but also to moral theory. For we agree with Kant that moral constraints must apply in the absence of other-directed interests" (1986, p. 100).

So, as Kirzner (1990) and Machan (1989, pp. 25-30) have also observed, using other examples, it looks logically necessary to many economists and their critics that the assumption of self-interest cannot be made compatible with altruism. But this is not so.

Let us separate two false views on altruism:

1. People are necessarily psychological egoists and hence never altruists. The argument can be put thus: one cannot help others unless one thereby achieves personal satisfaction, in some sense, so apparently altruistic people give up nothing for they are following their self-interest as much as anyone else.

2. The assumption of self-interest must be false or vacuous because it is obvious that people are often selflessly altruistic. ${ }^{11}$

Why are these two views false?

"Altruism" means "other-regardingness" or "other-interestedness" in the sense of seeing another as an end in himself. "Self-interest" is popularly used to mean purely self-regarding or self-interested, and so is incompatible with altruism. There is nothing categorically incorrect about using "self-interest" in a sense that means what is also called "egoism." That is obviously a more common way to use the term. But being self-interested can be interpreted in the Austrian economic sense as merely following whatever interests one has oneself. It is possibly clearer for economic apriorists to label "self-interest" as "self-perceived interest" to help to avoid confusion. The point is that it is not necessary to understand economic "self-interest" in the narrow sense. In the apriorist sense, "self(-perceived)-interest" can embrace altruism; for altruism then means having an interest in others as ends in themselves. 
This position can be set out as follows:

Self(-Perceived)-Interest: in the broad apriorist sense, all interests (or desires, wants, values; these are not distinguished here) are interests of the self. We cannot have purely selfless interests, for we must feel an interest that is ours to the extent that we are proper agents with motives.

But such interests of the self can still intelligibly be divided thus:

Egoism: an interest in one's own ends and in other people or things, if at all, as mere means to one's own ends;

Altruism: an interest in other people, or even things, as ends in themselves.

Consider Hobbes' action of giving alms to a beggar. He stated that he gave only to relieve his own distress. That Hobbes took any interest in the beggar means that the interests of Hobbes' included the circumstances of the beggar. Thus his action was self-interested in the broad Austrian sense. We can go on to ask whether Hobbes was being egoistic or altruistic. If Hobbes were merely upset at the ugly sight of the beggar, and would rather that he had never seen him, then we can say that his behavior was egoistic: he did not view the beggar as a valuable thing in himself but as a nuisance. This is a natural interpretation to put on Hobbes' explanation of his behavior. But if Hobbes was really taking pity on the beggar as an end in himself, and would wish him to be better off whether or not Hobbes knew about it, then his behavior was altruistic. In both cases we have self-interest in that Hobbes himself has the beggar as one of his interests. In reality, it might well have been that Hobbes both found the beggar a nuisance and had some sympathy with him. So his gift would be motivated by both irritation and pity. Neither feeling would be more real than the other in the sense that the irritation showed him not to be really altruistic at all or the pity showed him not to be really egoistic at all. Both his egoistic interests and his altruistic interests are objectively his self-perceived interests.

In my experience, some trained economists see the above argument as a mere proof of psychological egoism. A thought-experiment might show the reality of altruism more clearly. The devil stops time during a family car crash and offers the husband a choice of (1) the rest of the family dying but his happily forgetting them, or (2) the rest of the family surviving but his miserably thinking them dead. That " 2 " would be a possible, even likely, choice shows that real altruism is possible. To choose "2" must be to desire the good of others as ends in themselves rather than for any satisfaction, in whatever sense, they might bring us. But this does not show that we are not "self-interested" in the apriorist economic sense.

It is an error to think that economics requires the assumption of egoism, or "non-tuism." There need be no particular problem with allowing that people can have interests that embrace promoting (or destroying, come to that) the interests of others. Of course, it will sometimes be useful for economic analysis to distinguish what kinds of self-perceived interests are in operation; but there is no need to think that the altruistic kinds (ideology, charity, etc.) are ipso facto beyond economic analysis.

It is difficult for some people to accept that altruism can innocuously be seen as part of self(-perceived)-interest. Part of the problem relates to a conception of morality that is rather prevalent, but which is dissented from here. First we shall look at that, and then at some typical critics of apriorist self-interest. 


\section{The Intentional Structure of Moral Sentiments}

Here I discuss the intentional structure of moral sentiments. In doing this, I hope to focus on the form or nature of morals as such-in what sense they exist, rather than the content or particular moral views. Thus this is non-moral, or non-ethical, as regards advocatory content. Why is this discussion here? It helps to explain how morals are compatible with economics. Thus morals do not trump economic analysis, or vice versa. If this account is not purely descriptive, due to the nebulous nature of moral sentiment, then it is at least maximally rationalist. It allows more and bolder views to count as moral views.

Morality is correctly seen as having to be impartial in some sense. Yet it seems that morality has to be held as a personal value and is thus also partial in some other sense, or there would be no motivational explanation. Kant reacted to the threat to morality posed by the Hobbesian-type of self-interest argument by trying to make morality almost a purely logical affair (1785). He held that an act is moral only to the extent that all can will it without contradiction. There must be no personal desire involved, though he does allow respect for the moral law. Thus Kant correctly perceived that morality is impartial in some way, but he opted for a pure impartiality that leaves no clear room for motivation. ${ }^{12}$ (Though the Kantian test of whether something is done morally can charitably be interpreted as whether we would have done it even if we felt no egoistic desire for it, plus whether it is universalizable.)

Bishop Butler's response to Hobbes seems approximately correct (1726). He agreed with the insight that all interests must be interests of the self, but denied that this entails that we are self-interested in any narrow sense, that we must be interested in the self alone. He held that Hobbes had overlooked the real distinction we have in our goals. ${ }^{13}$ But Hume's view of moralizing seems to capture the correct account more clearly. He writes that we feel "some sentiment of blame or approbation, whence we pronounce the action criminal or virtuous" (Treatise, 1740, Book III, Part I). This thus views moralizing as (1) the personal emotional evaluation of a type or principle of behavior (2) irrespective of the interests of a particular agent. This thus catches both (1) the partial and (2) the impartial aspects of moralizing. This needs to be elaborated.

1. We have partiality in one way. For the very fact that the individual sees a certain general group of agents and type of behavior as being of value, or disvalue, shows that he is partial to these. This partiality is usually overlooked, or felt to make a moral view somehow less moral, because people often feel that moral views must somehow be completely impartial. ${ }^{14}$ But without this partiality we have no motivation (how the individual becomes partial to certain groups or types of behavior is a separate issue).

2. We have the impartiality in the altruistic sense that the evaluation is not specific to the agent and his/her immediate and personal goals. The agent has to be able to affirm the evaluation even when he/she does not know who in particular is involved. But the group of persons among whom the agent is impartial in the agent's judgement need not be as large as all human beings. ${ }^{15}$ The agent is, rather, impartial within the domain of some group that matters to the agent. ${ }^{16}$ The group might also be larger than that of all human beings and include animals and plant life or even inanimate matter. It is even morally coherent to discriminate against human beings as being immoral or worth less than other species or some abstract goal. 
One might think that an attempt to respect, say, justice as such would mean that I could not discriminate between my group and other groups. But justice is a formal concept, like desert and impartiality. One needs principles and groups, and that entails discrimination, before one can use the formal concept. Perhaps this is obscured by two popular views: that either the group in moral matters ought always to include all human beings or that the principle must be utilitarian. But these views clearly discriminate in favor of a particular group or principle, and thus discriminate against other groups or principles.

Thus every moral sentiment is group- and principle-partial, but also individualimpartial. I am "self-interested" in that I am bound to want only things $I$ value, but some of the things I value are altruistically and morally valued. This is not supposed fully to capture the nature of moralizing, but it should be relevantly more accurate than that of the critics of apriorist self (-perceived)-interest that we are about to examine.

\section{Commitment, Motive-Stimuli, and Vacuousness}

Amartya Sen, C. D. Broad, and Tibor Machan want a pure impartiality that excludes any clear self-referential motive - though Sen and Machan are attacking economics as such, whereas Broad is attacking psychological egoism. David Ramsay Steele agrees with Machan in finding the a priori approach to be vacuous. I will now consider their criticisms.

In his "Rational Fools," Amartya (Sen, 1979) asserts that economics' self-interest assumption rules out "commitment" or is vacuously true. As he thinks that people obviously do feel real commitment, he rejects the motivational exclusiveness, or vacuousness, of the self-interest assumption. Sen holds that economics must be supplemented with a richer view of human nature that allows room for morals in economic analysis. He appears to conflate the Hobbesian assumption of egoistic self-interest-he mentions Butler's attack on this-with economics' revealed preference theory, whereby "if you are observed to choose $x$ rejecting $y$, you are declared to have 'revealed' a preference for $x$ over $y$ (Sen, 1979, pp. 91-92)." Sen complains that "no matter whether you are a single-minded egoist or a raving altruist or a class conscious militant, you will appear to be maximizing your own utility in this enchanted world of definitions" (p. 92). And he objects to the idea that choices are only "rational" if they "can be explained as the choosing of 'most preferred' alternatives" (p. 92).

Sen apparently believes that we sometimes do what we do not, under the circumstances, most prefer to do. He offers an alternative approach that takes account of commitment, which includes morality "in a very broad sense" (p. 97). He suggests that "commitment" can be defined as occurring where a person chooses "an act that he believes will yield a lower level of personal welfare to him than an alternative that is also available to him" (p. 95). Well that sounds acceptable - at least, at first—for it has been argued that we do sometimes forgo egoistic welfare to help others for their sakes. But Sen continues: "commitment does involve, in a very real sense, counterpreferential choice, destroying the crucial assumption that the chosen alternative must be better than (or at least as good as) the others for the person choosing it" (p. 96).

How can we make a "counterpreferential choice"? How can we choose to do what we do not in some sense prefer to do? Must not the chosen alternative be better for us in some sense? Otherwise, where is the personal motivation? Sen goes further and approvingly quotes a character who says of his action, "I had no motive and no interest" (p. 97). Sen seems to have replaced an "enchanted world of definitions" (where all actions can be seen as analytically 
self-interested) with a world without any motives at all. He feels he has to do this as he cannot allow sympathy to be part of "commitment" because "behaviour based on sympathy is in an important sense egoistic, for one is oneself pleased at others' pleasure and pained at others' pain" (p. 95).

He wants to make sense of a pure impartiality that entirely escapes sympathy. But Sen's "commitment" (i.e., morality) must be being impartial in some way within the group to which one is partial. If my earlier account of morality is correct, then one cannot have a moral commitment that escapes sympathy (in a broad sense of "sympathy"). Even the more general sense of subjective, "commitment" just seems to mean feeling emotional engagement of some kind. Without some personal sentiment we would not be committed and so could not act out of commitment. ${ }^{17}$ Sen will not allow an Austrian-type interpretation of self-interest because he accepts the mistaken conception of morality discussed earlier: he hankers after a "pure" impartiality in morality that is impossible because it leaves no room for the necessary sentimental, or emotional, motive. So Sen's views on definitions in economics only partly repeat what Butler wrote in response to Hobbes. For Sen overlooks Butler's insight that Hobbes' position on personal motivation is essentially correct but still leaves room for real altruistic goals.

C. D. Broad (1950) is right to attack psychological egoism, as held by Hobbes, as a false theory of human motivation. He is mistaken in failing to see that altruism must still be selfinterested in the sense under discussion. Like Sen, he appears to opt for altruism without the necessary self-referential motive, for he also seems mistakenly to think that Butler refuted Hobbes on this issue. Broad admits that the desire of a mother for the good of her child "is self-referential, because the fact that it is her child and not another's acts as a powerful motivestimulant" (p. 252). This is fine as far as it goes. Broad is right in seeing that such altruism refers back to the self. He is wrong only in failing to see that all altruism refers back to the self in a similar sense.

Consider Broad's main example: "a person who deliberately chooses to devote his life to working among lepers, in the full knowledge that he will almost certainly contract leprosy and die in a particularly loathsome way" (p. 256). It can immediately be conceded that the real motive might be that the man simply wants to help the lepers. And it can be agreed that this is an other-regarding motive: he values the lepers for their own sakes. But, to use Broad's terminology against himself, we can say that the lepers are indeed acting as a "powerful motivestimulant." Broad tries to rule this out by stipulating that the lepers are not the man's "relatives nor his friends nor his benefactors nor members of any community or institution to which he belongs" (p. 257). But it seems that the man must view them as members of his (moral) community in some sense (perhaps the "community of humanity") or he would not so act. Some people may be so constituted that they care as much about strangers as most people do only about their immediate family. Unless this individual has some such feeling he would not act as described. So we must extend Broad's notion of the so-called "egoistic motive-stimulus" (p. 256) to cover his otherwise motiveless altruistic actions. The man is motivated by finding that the thought of helping the lepers for their own sakes more satisfies his wants than not helping them-or he would not do it. The self-referential motivation that Broad explicitly tries to rule out is a necessary part of being altruistic.

Tibor Machan is an interesting critic of the Austrian interpretation of the self-interest assumption in economics. He is sympathetic with the free-market results of mainstream economics, and he is sympathetic with the idea that people should be positively egoistic (he is a libertarian influenced by Ayn Rand). He is familiar with the recent suggestion from Public 
Choice School economics that it is sensible to include ideological factors to explain politicians' behavior. He knows that the "economic imperialists" are happy with self(-perceived)interest embracing morality, but he is not. The sticking point for Machan is the idea that a mere definition can be so pervasive. As Machan puts it (1990, pp. 25-26): ${ }^{18}$

Any factor or model that explains anything whatever-for example, self-defeating as well as selfserving conduct-simply explains nothing much! If the model fully explains the bank-robber as well as the banker, what can we learn from the explanation? In no science would this kind of approach be admitted; the melting of ice explained by the same factor as the freezing of water, private interest! ...

In order to avoid this vacuousness, the "ideological variable" has to be seen as adding a dimension, namely what kind of conduct human beings take to be proper, what they see as binding on them quite apart from what they prefer.

I have already dealt with the idea that there could be "conduct human beings take to be proper ... quite apart from what they prefer." Here the charge of "vacuousness" is considered. Is the self-interest assumption tautologous? It depends on how it is interpreted. If it is taken to mean that people (as distinct from people's actions) are motivated by their self(-perceived)interests then it is not tautologous. We can make sense of a person's behaving (in the sense of moving) in a non-self-interested way, and thus we can conceive of falsifications. For instance, if people's bodies were controlled by other minds then they would not be pursuing their own self-perceived interests; nor would they if their bodies spontaneously behaved in ways they could not consciously control, as happens to some extent with epileptic fits, twitching nerves, movements during sleep (I guess that sleepwalking is a more or less conscious activity, albeit in an unusual mental state). Sustained constructive examples ought to sound far-fetched. The assumption that people are motivated by self-perceived interest is supposed to be an almost universal truth, but it is not a tautology. If, on the other hand, the assumption is the Austrian economic one that all actions are self-interested, then it is, roughly speaking, tautologous-or if not strictly tautologous (for it is not clear that the meanings of the terms make it true) then a priori (for it can be known independently of experience). For any action to be an action it must mean that an individual is moving his/her body as a result of his/her self-perceived interests. If the body were moving automatically or as a result of another's will then the individual qua individual would not be acting. So the idea that people (not actions) are motivated by selfperceived interest can be seen as a highly accurate approximation that is based on the apriorism about agents.

However, this apriorism is not viciously vacuous or any kind of a threat to the scientific nature of economics. On the contrary, it is an enlightening apriorism that allows fruitful economic analysis to proceed. The fact that an individual is assumed to be thus self-interested does not in itself tell us anything about the particular values and beliefs of the individual. The hard work of explaining what is going on in some economic situation is often in making shrewd guesses and testing them. Having a theoretical framework is not the same as already having an explanation. If an engineer is called in to discover why a bridge fell down, then he might already have the theoretical tools for the job but he will hardly have the specific explanation. Only in an innocuous sense are the theoretical tools of the economist and engineer "vacuous," because the work of filling in the details of any real solution has not yet been done. 
David Ramsay Steele (1992, p. 98) voices similar objections to Machan's: “A determined praxeologist can account for every vagary (as Mises did: 1966, 103) by positing a different end-means scheme in each case, and in that way rescue the apodictic certainty of praxeology, but this would be at the cost of rendering it inapplicable because all too promiscuously applicable." On the contrary, action that does not fit the supposed end-means scheme is begging for the, possibly difficult, task of suggesting a plausible, testable, enlightening new theory of the motive in operation. The alternative is idly, promiscuously, and unenlighteningly to assert "irrationality." Fortunately, Austrian rationality can only fail to apply if the individual fails to be an agent. Steele's major example of unreality in Austrian assumptions is that of consistent preferences. But as Rothbard points out (1956, p. 229), this criticism is confusing constant preferences, which certainly need not exist, with consistent ones.

As Kirzner (1960/1972, p. 172; emphasis added) writes: "The description of all human action as rational constitutes a proposition that is, in fact, incapable of being falsified by any experience, yet does, nevertheless, convey highly valuable information." But again, this assumption is not specific to any notion of economic man. There is no substantive theory of human nature here. This notion of self-interested motivation is naturally applicable to all beings capable of action.

\section{Notes}

1. The a priori/a posteriori distinction (that we know some things independently of/not independently of experience) is a matter of philosophical controversy. It has been challenged, for instance, by Lakatos (1976) and Quine (1980, 21ff). Bartley (1990, p. 240) completely agrees with Lakatos in rejecting the distinction. However, I see no convincing reason for not entertaining the distinction critically or conjecturally, as Bartley himself does with "necessary truths" (p. 239): we are entitled to conjecture that we know a priori that agents are rational, in the sense to be defined, given that we cannot think of any logical argument or empirical evidence that would refute the thesis but concede that this could just be our failure of imagination. In any case, it seems wise to stick to this distinction as used by Mises, Kirzner, and Rothbard until there are better arguments that it has to be abandoned.

There are complicated arguments on the relationships among the three pairs of concepts: a priori/a posteriori, necessary/contingent, and analytic/synthetic. I have ignored these as being distractions and used the terms in philosophically orthodox ways.

2. For brief but sophisticated accounts of Austrian apriorism generally see Smith, 1986 and 1990.

3. They quote Mises in the introduction to the second chapter, but their conception of rationality is not fully comprehensive and a priori, as they explicitly concede (p. 30).

4. For a general criticism and defence of Austrianism see, respectively, Nozick, 1977 and Block, 1980.

5. In a broader sense of "interest," something can be in one's interests without one's desiring it. Elsewhere I argue (Lester, in press) that such interests must relate to a real-felt interest at some point, and that it is more welfare-efficient in practice to allow people to make errors than impose one's perceptions of their interests.

6. If it is not true that firms tend to maximize their profits ultimately because that in some way tends to maximize the want-satisfaction of the people involved, then the assumption that firms do throws doubt on any economic conclusions that are supposed to follow (though firms might need to approximate a profit-maximizing strategy if they are to survive at all).

7. For a useful account of the debate between Kirzner and Becker on this issue, and what is at stake, see Lagueux, 1991. 
8. Though some of the best economists of their time did not make this assumption: Hume, Smith, Wicksteed, and Marshall.

9. As a consequence of such economic work, this Professor of Economics at Chicago has also been made a Professor of Sociology.

10. Becker gnes on to give an economic analysis of altruism. He argues that it increases genetic reproduction in various ways, and hence it is really a sort of genetic egoism.

11. Alasdair MacIntyre (1967) expresses these two views thus: "philosophers have oscillated between these two positions: the Hobbesian doctrine of altruism as either a disguise or a substitute for self-seeking and the assertion of an original spring of altruistic benevolence as an ultimate and unexplained property of human nature."

12. Hare cites Kant in his support, and I think that he therefore fails to see that Kant's moral system lacks a clear emotional motive. Like Kant, he thinks morals are decided rather than felt (e.g. Hare, 1952, p. 44 and p. 54).

13. In Butlerian terminology, however, only actions done out of self-love, the desire for one's own happiness, are sensibly called "interested"; actions done for any other motives are "disinterested."

14. E.g., Singer, 1983, especially ch. 6.

15. Contra the many moral philosophers who hold this view (such as Mackie, 1979 and Hare, 1952), which seems to be imposing unnecessary content on the form of moralizing.

16. It might even be only oneself that is valued morally, perhaps because one feels that all people should neglect others (moral egoism), or because one feels one has qualities that simply happen to put one above others, but such person would respect anyone who were to come to have these qualities. Both of these are still being formally impartial.

17. One can also have objective commitments, such as contractual obligations, but Sen does not mean these. One need not be subjectively committed to one's objective commitments.

18. As Ray Percival observed on reading this, the melting and freezing examples are in a sense explained by the same factor, temperature, but going in different directions.

\section{References}

Bartley, W. W., III. (1962/1990) The Retreat to Commitment, 2nd ed. La Salle, IL: Open Court.

Becker, G. S. (1962) "Irrational Behaviour and Economic Theory." Journal of Political Economy, 70, 1-13.

Becker, G. S. (1971) “Altruism, Egoism, and Genetic Fitness." Journal of Economic Literature, 14.

Becker, G. S. (1976) The Economic Approach to Human Behavior. Chicago: University of Chicago Press.

Block, W, (1980) “On Robert Nozick's `On Austrian Methodology'.” Inquiry, 23, 397-444.

Broad, C. D. (1950/1971) "Egoism as a Theory of Human Motives," in Cheney, D., ed. Critical Essays in Moral Philosophy. London: Allen and Unwin.

Butler, J. (1726/1967) Fifteen Sermons Preached at the Rolls Chapel. London: Bell.

Edgeworth, F. Y. (1881/1935) Mathematical Psychics. London: Kegan Paul.

Friedman, M. (1953) Essays in Positive Economics. Chicago, IL: University of Chicago Press.

Gauthier, D. (1986) Morals by Agreement. New York: Oxford University Press.

Hare, R. M. (1952/1986) The Language of Morals. Oxford: Oxford University Press.

Hirshleifer, J. (1984) Price Theory and Applications, 3rd ed. London: Prentice-Hall.

Hobbes, T. (1651/1943) Leviathan. London: Dent.

Hume, D. (1739-1740/1968) A Treatise of Human Nature, Selby-Bigge, L. A.. ed. Oxford: Oxford University Press.

Kant, I. (1785/1948) "Groundwork to the Metaphysic of Morals," in Paton, H. J., ed. The Moral Law. London: Hutchinson. 
Kirzner, I. M. (1960/1976) The Economic Point of View. New York: Sheed and Ward.

Kirzner, I. M. (1990) "Self-Interest and the New Bashing of Economics: A Fresh Opportunity in the Perennial Debate?" Critical Review, 4.

Lagueux, M. (1991) "Kirzner vs. Becker: Rationality and Mechanisms in Economics," in Hebert, R. F., ed. Perspectives on the History of Economic Thought, Volume IX. Aldershot, UK: Edward Elgar.

Lakatos, I. (1976) Proofs and Refutations: The Logic of Mathematical Discovery. London: Cambridge University Press.

Lester, J. C. (in press) Liberty, Utility, and Anarchy: A Libertarian Reconciliation. Lanham, MD: Rowman \& Littlefield.

Machan, T. (1989) Individuals and Their Rights. La Salle, IL: Open Court.

Machan, T. (1990) Capitalism and Individualism. New York: St. Martin's Press.

MacIntyre, A. (1967) "Egoism and Altruism," in Edwards, P., ed. The Encyclopaedia of Philosophy, London: Macmillan.

Mackenzie, R. B. \& Tullock, G. (1978) Modern Political Economy: An Introduction to Economics. New York: McGraw-Hill.

Mackie, J. L. (1977/1979) Ethics: Inventing Right and Wrong. Harmondsworth, UK: Penguin.

Mises, L. E. von. (1949/1966) Human Action: A Treatise on Economics, 3rd rev ed. Chicago: Contemporary Books.

Nozick, R. (1977) “On Austrian Methodology." Synthese, 36, 353-392.

Quine, W. V. O. (1980) From a Logical Point of View. Cambridge, MA: Harvard University Press.

Rothbard, M. N. (1956) "Toward a Reconstruction of Utility and Welfare Economics," in Sennholz, M., ed. On Freedom and Free Enterprise. Princeton, NJ: Van Nostrand.

Sen, A. K. (1976/1979) "Rational Fools," in Hahn, F. \& Hollis, M., eds. Philosophy and Economic Theory. Oxford: Oxford University Press.

Singer, P. (1981/1983) The Expanding Circle: Ethics and Sociobiology. Oxford: Oxford University Press.

Smith, B. (1986) "Austrian Economics and Austrian Philosophy," in Grassl, W. \& Smith, B., eds. Austrian Economics: Historical and Philosophical Background. London: Croom Helm.

Smith, B. (1990) "Aristotle, Menger, Mises: A Essay in the Metaphysics of Economics," in Caldwell, B. J., ed. Carl Menger and his Legacy in Economics. Durham, NC: Duke University Press.

Steele, D. R. (1992) From Marx to Mises: Post-Capitalist Society and the Challenge of Economic Calculation. La Salle, IL: Open Court.

\section{Acknowledgements}

This essay is derived from a chapter on "Apriorist Instrumental Rationality" in the author's forthcoming Liberty, Utility, and Anarchy: A Libertarian Reconciliation (Rowman \& Littlefield).

\section{About the Author}

Jan Lester is the author of Liberty, Utility, and Anarchy: A Libertarian Reconciliation (Lanham, MD: Rowman \& Littlefield, in press). He teaches philosophy at Middlesex University, in London, and Hertfordshire University. His most recent previous article in the Journal was “Popper's Epistemology versus Popper's Politics: A Libertarian Viewpoint," in vol. 18, no. 1. 